\title{
Trees on Farm Domestication Level, Opportunities and Challenges: A Case Study of Prunus africana in Western Kenya
}

\author{
Gachie P. K. ${ }^{1, *}$, Koech E.K. ${ }^{2}$, Njung'e J.T. ${ }^{3}$, Simons A.J. ${ }^{4}$ \\ ${ }^{1}$ Kenya Forestry Research Institute, Kenya. \\ ${ }^{2}$ University of Kabianga, Kenya. \\ ${ }^{3}$ University of Namibia, Namibia. \\ ${ }^{4}$ World Agroforestry Centre, Kenya.
}

How to cite this paper: Gachie P. K., Koech E.K., Njung'e J.T., Simons A.J. (2020) Trees on Farm Domestication Level, Opportunities and Challenges: A Case Study of Prunus africana in Western Kenya. International Journal of the Science of Food and Agriculture, 4(2), 156-165.

DOI: $10.26855 /$ ijfsa.2020.06.007

Received: March 11, 2020

Accepted: April 8, 2020

Published: May 12, 2020

"Corresponding author: Gachie P. K., Kenya Forestry Research Institute, Kenya.

Email: pgachie@yahoo.com

\begin{abstract}
Prunus africana, is widely known for its medicinal value. The tree has being overexploited for its bark highly valued remedy against prostate disorders. One way of conserving it, is through its domestication. There is a need to assess the potentials and constraints to its domestication. The objective of this study was to generate information to improve strategies for its conservation and domestication in Kenya. A survey was done on farms adjacent to Kobujoi and Kakamega forest reserves (western Kenya) using a semi-structured questionnaire. The results indicate that farmers in Kobujoi were more aware of $P$. africana uses than those in Kakamega. Firewood recorded the highest frequency of use in both areas while its medicinal use ranked third. In Kobujoi, the species competition with the agricultural crops was the main constraint while in Kakamega, certain discouraging customs and beliefs ranked highest. Lack of seedlings was also a common constraint.
\end{abstract}

\section{Keywords}

Prunus africana, Cultivation, Constraints, Utilization, Western Kenya

\section{Introduction}

\subsection{Background Information}

In the pre-colonial era, trees that grew in Kenya were mostly indigenous with a high species diversity. Natural forests were later cleared or valuable timber species were extracted and replaced by other land uses such as agriculture, plantation forests, human settlement among others. The introduction and promotion of agroforestry systems enhanced the use of exotic tree species at the expense of the indigenous ones in the country [1]. This lead to a rapid decline of indigenous trees species, Prunus africana being included.

Prunus africana, commonly known as red stinkwood, is an evergreen tree, up to $30 \mathrm{~m}$ in height, with a stem diameter of up to $1 \mathrm{~m}$, the bark is blackish-brown and rugged and branchlets are dotted with breathing spots [2]. It has a heavy, shining foliage composed of alternate, simple leaves, oval or lance shaped, which when crushed have a bitter-almond smell. Its flowers are small, white or greenish in colour. P. africana, is a highland forest tree, growing in the humid and semi-humid highlands and humid midlands. In Kenya, it naturally grows on the slopes 
of Mt Kenya, Mt Elgon, the Aberdares Range, Cherangani Hills, Tugen Hills, Mau Range, Timboroa, Nandi and Kakamega Forests. It is mostly found in association with species such as Albizia gummifera, Aningera adolfi-friederici, Cassipourea malosana, Celtis africana, Podocarpus falcatus and Polyscias kikuyuensis. The species has a high light requirement and grows best in forest gaps [2].

The tree species is widely known for its medicinal value, control of soil erosion, high quality firewood, mulch and green manure, bee forage and shade [3]. It is also used for both structural and furniture timber, poles and making mortars. The species has of recent past, also being overexploited as its bark has a high cash value in the international trade as a remedy against prostate disorders, leading to the species being threatened with extinction [4] [5].

The harvest of mature, seed producing trees severely reduces natural regeneration and destroys the natural resource base in collection areas thereby interfering with production of seedlings. The tree is restricted to areas with altitude of $1,000 \mathrm{~m}$ and above, grows slowly, has recalcitrant seeds and does not maintain a large seedling bank in the forest understorey posing a great problem in regeneration in the natural environment. Natural populations of Prunus africana also present management problems because of low and patchy stocking levels and the frequent under-representation of small individuals.

There is therefore need to conserve the species. One of the recommended ways of conserving this species is through its domestication. "Domestication of trees involves accelerated and human-induced evolution to bring species into wider cultivation through a farmer-driven or market-led process. This is an interactive procedure involving the identification, production, management and adoption of desirable germplasm" [6]. Since the farmers have vested interest on the crops and trees they grow, the deliberate cultivation of $P$. africana on their farms potentially promises a sustained supply of its products. This will be motivated by the cash value of the bark and the security of future harvests. However, its introduction into the farms is bound to face some challenges and hence the need to assess the level, potential and constraints to its domestication in some areas that the species is naturally found.

\subsection{Objectives of the study}

The overall goal was to generate information for improving conservation and domestication of Prunus africana on farms in Kenya.

The specific objectives were:

1) To assess the domestication level of $P$. africana and other common tree species on farms adjacent to South Nandi/ Kobujoi and Kakamega forest reserves.

2) To identify the potentials and constraints for $P$. africana growing on farms adjacent to Kobujoi and Kakamega forest reserves.

\section{Materials and Methods}

\subsection{Study sites}

The assessment of level and character or manner of tree planting was done on farms adjacent to Kobujoi and Kakamega forests in western Kenya. The sites were selected on the basis of natural availability and ecological distribution of Prunus africana together with the geographical and cultural or user differences of people living adjacent to the forest reserves involved in the survey.

\subsection{Farm survey}

Farm survey was conducted for assessment of the distribution, uses and constraints to domestication of Prunus africana in the farms adjacent to Kobujoi and Kakamega forest reserves. The survey was aided by the use of a semi-structured questionnaire. A total of 72 farmers (36 each from both Kakamega and Kobujoi) were interviewed and the answers given were incorporated with the general observations made in the farms. In addition to filling the questionnaires, physical counting for all Prunus africana trees growing on farms was made. The data was analysed and presented in graphs and tables.

\subsection{Sampling procedure in farms selection}

A stretch of about 10 kilometers running along Kobujoi forest edge was demarcated. A second stretch of the 
same length $(10 \mathrm{~km})$, was demarcated about 2.5 kilometers from the forest edge while the third transect was made about 5 kilometers from the forest edge. For every transect, 12 farms were sampled systematically (after every 0.8 $\mathrm{km}$ ) and used for the survey. Similar stretches were demarcated on farms adjacent to Kakamega forest reserve.

\section{Results and Discussion}

\subsection{Level of trees domestication in Kobujoi and Kakamega forest areas}

In all the sampled farms adjacent to Kobujoi and Kakamega forest areas, tree farming was prevalent. Kobujoi, however, had more tree species (57) than Kakamega (49) (Appendix I). Some 31 tree species were common in both areas in varying intensities. Generally, Kobujoi observed more farmers (25) who had Prunus africana on their farms than Kakamega area (20). The most commonly grown tree species in the study areas and their reported uses are shown in Tables 1 and 2 below.

Table 1. Ten most frequently occurring tree species in farms adjacent to Kobujoi forest reserve and their uses

\begin{tabular}{|c|c|c|c|c|c|c|c|c|}
\hline \multirow{2}{*}{ Tree species } & \multicolumn{8}{|c|}{$\%$ of farmers reporting the use of tree species as: } \\
\hline & $\mathrm{CC}$ & FW & $\mathrm{CN}$ & $\mathrm{FC}$ & MD & SD & TB & FR \\
\hline Croton macrostachyus & 31 & 83 & 3 & 6 & 42 & 56 & 44 & 0 \\
\hline Croton megalocarpus & 39 & 92 & 6 & 11 & 14 & 47 & 47 & 0 \\
\hline Cupressus lusitanica & 0 & 58 & 22 & 33 & 0 & 17 & 72 & 0 \\
\hline Eriobotrya japonica & 0 & 44 & 0 & 8 & 0 & 33 & 0 & 56 \\
\hline Eucalyptus spp & 3 & 81 & 36 & 42 & 0 & 0 & 75 & 0 \\
\hline Markhamia lutea & 3 & 53 & 33 & 22 & 8 & 22 & 44 & 0 \\
\hline Persea americana & 0 & 25 & 0 & 0 & 0 & 31 & 0 & 44 \\
\hline Polyscius fulva & 0 & 47 & 3 & 0 & 3 & 11 & 47 & 0 \\
\hline Prunus africana & 11 & 64 & 3 & 11 & 28 & 11 & 61 & 0 \\
\hline Zanthophyllum gillettii & 6 & 47 & 0 & 0 & 47 & 0 & 58 & 0 \\
\hline
\end{tabular}

Key

$\mathrm{FW}=$ Fuelwood

$\mathrm{SD}=$ Shade $\mathrm{CN}=$ Construction poles

$\mathrm{TB}=$ Timber

$\mathrm{FC}=$ Fencing

$\mathrm{FR}=$ Fruits $\mathrm{MD}=$ Medicine

$\mathrm{CC}=$ Charcoal

Table 2. Ten most frequently occurring tree species in farms adjacent to Kakamega forest reserve and their uses

\begin{tabular}{|c|c|c|c|c|c|c|c|c|}
\hline \multirow{2}{*}{ Tree species } & \multicolumn{8}{|c|}{$\%$ of farmers reporting the use of tree species as: } \\
\hline & $\mathrm{CC}$ & FW & $\mathrm{CN}$ & $\mathrm{FC}$ & MD & SD & TB & FR \\
\hline Croton macrostachyus & 53 & 83 & 0 & 0 & 11 & 11 & 58 & 0 \\
\hline Cupressus lusitanica & 3 & 72 & 22 & 19 & 0 & 0 & 78 & 0 \\
\hline Eucalyptus spp & 3 & 81 & 31 & 28 & 3 & 0 & 86 & 0 \\
\hline Grevillea robusta & 8 & 44 & 3 & 0 & 0 & 3 & 50 & 0 \\
\hline Mangifera indica & 0 & 31 & 0 & 0 & 0 & 6 & 0 & 42 \\
\hline Markhamia lutea & 0 & 44 & 31 & 28 & 6 & 3 & 56 & 0 \\
\hline Olea capensis & 8 & 44 & 0 & 0 & 50 & 0 & 50 & 0 \\
\hline Persea americana & 3 & 58 & 0 & 0 & 0 & 8 & 3 & 75 \\
\hline Prunus africana & 19 & 44 & 3 & 0 & 17 & 0 & 50 & 0 \\
\hline Zanthophyllum gillettii & 17 & 50 & 0 & 0 & 64 & 0 & 64 & 0 \\
\hline
\end{tabular}

Key

$\mathrm{FW}=$ Fuelwood $\quad \mathrm{SD}=$ Shade $\mathrm{CN}=$ Construction poles $\quad \mathrm{TB}=$ Timber

$\mathrm{FC}=$ Fencing $\quad \mathrm{FR}=$ Fruits $\mathrm{MD}=$ Medicine $\quad \mathrm{CC}=$ Charcoal

A study by [7] in Tanzania indicates that $P$. africana is among the most preferred species, ranking fourth 
amongst ten most preferred trees in the study area. Other important trees mentioned by respondents were Cordia africana, Grevillea robusta and Cupressus lusitanica. In Cameroon, [8], found that P. africana is mostly cultivated as a cash earning enterprise, an important medicine for home consumption and other multiple products such as handles for axes and hoes, mulch and green manures, firewood, poles and seed sales. A study carried out in Chapereria Division West Pokot County Kenya by [9] had 25 medicinal trees and shrubs while [10] found 17 major multipurpose tree species growing on farms at Kapsaret division of Uasin Gishu county in Kenya. [10] also found out that trees on farm are utilized for fodder (10\%), soil fertility improvement $(47 \%)$ while timber and fuel accounted for $77 \%$.

\section{Occurrence and planting niche of Prunus africana}

More farmers had Prunus africana trees in their farms in Kobujoi $(n=25)$ than in Kakamega $(n=20)$. The species appeared as both planted and naturally occurring in both areas (Table 3).

Table 3. Nature of occurrence of Prunus africana by farm holdings in Kobujoi $(n=25)$ and Kakamega $(n=20)$ forest areas

\begin{tabular}{cccc}
\hline & \% of farmers where the species occurred \\
\hline Study site & As planted stock & Naturally & Both planted and naturally \\
Kobujoi & 44 & 36 & 20 \\
Kakamega & 50 & 45 & 5 \\
\hline
\end{tabular}

The main planting niches for Kobujoi are on boundaries, watershed and on farm in a scattered manner. In Kakamega Prunus africana was mainly sighted on boundaries, scattered on farm and as woodlots (Table 4).

Table 4. Main planting niche of Prunus africana on farms in Kobujoi $(n=111)$ and Kakamega $(n=77)$

Proportion (\%) of Prunus africana trees at:

\begin{tabular}{ccc} 
Planting niche & Kobujoi & Kakamega \\
\hline Boundary planting & 58 & 51 \\
Trees on watershed areas & 20 & 9 \\
Trees scattered on the farm & 14 & 27 \\
Trees on homestead & 8 & 1 \\
Woodlot & 0 & 12 \\
\hline
\end{tabular}

According to the respondents of Kakamega, the tree was not supposed to be planted but rather should grow on its own. If planted, it was a bad omen and associated with death of members of the concerned family. For the same reason, it was also not allowed to grow near a homestead. That is why there is minimal planting of Prunus africana near homestead in the area. Elsewhere, according to [8], P. africana was commonly mixed with other species in woodlots ( 4 of 10 farmers) on land where crops had not performed well. Other common niches, each planted by 4 of 10 farmers, included in coffee plantations, on boundaries, and scattered in food crops.

\subsection{Factors influencing planting/retention of Prunus africana on farms}

\section{Farmers knowledge of the use of Prunus africana}

The data collected indicate that farmers in Kobujoi are more aware of Prunus africana uses than those in Kakamega (Table 5). Firewood recorded the highest frequency of use in Kobujoi while timber was cited highest in Kakamega. Kobujoi farmers had extra knowledge of the species uses than those from Kakamega. The extra knowledge comprised of the species reported provision of shade, fencing material, mulch, bark sale and spearhead poison in Kobujoi. 
Table 5. Utilization or use knowledge of Prunus africana by farmers living adjacent to Kobujoi $(n=36)$ and Kakamega $(n=$ 36) forests

\begin{tabular}{ccc}
\hline Use & \% of farmers reporting a particular use of P. africana at: \\
& Kobujoi & Kakamega \\
\hline Firewood & 64 & 44 \\
Timber & 61 & 50 \\
Medicinal & 28 & 17 \\
Shade & 11 & 0 \\
Fencing & 11 & 0 \\
Charcoal & 11 & 0 \\
Mulch & 6 & 0 \\
Bark sale & 3 & 6 \\
Poles & 3 & 0 \\
Spearhead poison & 3 & 0 \\
\hline
\end{tabular}

As a multipurpose tree species, Prunus africana can positively contribute to the well being of the farmers. Its timber is of high quality (heavy, hard, tough and of above-average strength [11]). This makes it suitable for construction work as evident in Kobujoi and Kakamega areas. The same quality makes it preferred for fencing in Kobujoi. Firewood is another basic use of $P$. africana both in Kobujoi and Kakamega as it is the main source of energy for cooking food. This is in line with most of Kenyan rural population, of which $80 \%$ uses fuelwood as a source of fuel in their food preparation and warming their houses [12]. The species makes excellent firewood because its wood burns for long periods of time at high intensity [13]. Due to its evergreen character, Prunus africana is used in Kobujoi area to provide shade, acts as an ornamental tree and protects buildings from strong winds while planted near homesteads.

Forests and trees in particular, play a crucial role in health of many people [14]. The use of local drug plants varies from species to species, from distance to distance, from place to place, from time to time and even from person (medicine man) to person [15]. In Mwingi [16], and Kakamega [17] found 28 and 40 highly specialized tree species respectively, while in Marakwet [18] found a total of 111 tree species used for medicinal purposes. There are, of course, many similarities in the utilization of the plants as well. The Nandis and the Luhyas living in Kobujoi and Kakamega respectively, have a wide indigenous knowledge of medicinal trees (Table 1 and 2). More farmers from Kobujoi (28\%) were aware of the species medicinal value than in Kakamega (17\%). Prunus africana's use for medicinal purposes ranked third on both study areas, only after Zanthoxylum gillettii and Croton macrostachyus in Kobujoi and Zanthoxylum gillettii and Olea capensis subsp welwitschii in Kakamega. Elsewhere, according to [19] and [20], Prunus africana is the fourth most important traditional medicinal plant species in Cameroon.

Some diseases reported to be treated using P. africana by the locals were similar in both places (stomach ache and chest pain), while others were site specific (Table 6). Elsewhere, in Oku, traditional doctors use some Prunus africana bark in preparing nearly all traditional medicines; it is especially important in cures for stomach ailments ("belly bite"), fever, rheumatism, and gonorrhea. [21] have recorded Prunus africana as an important medicine for treating malaria, stomach ache and fever in the Ijim/Kom area. Use of the bark to treat stomach ache is also recorded from East Africa [15] and in Cameroon [22].

Table 6. Cited medicinal value of Prunus africana by farmers living adjacent to Kobujoi and Kakamega forests

\begin{tabular}{cl}
\hline Study area & \multicolumn{1}{c}{ Diseases reported to be treated by P. africana } \\
Kobujoi & (a) Human: Stomach ache (9\%), prostate cancer (4\%), gonorrhea (3\%), liver (3\%), chest \\
pain (3\%), cold (3\%), asthma (3\%). & (b) Livestock (cattle): Indigestion (3\%), diarrhea (3\%), placenta disorders (3\%), East Coast \\
& Fever (3\%). \\
Kakamega & (a) Human: Stomach ache (12\%) and chest pain (5\%).
\end{tabular}


The reliance of indigenous forests as sources of the bark is not sustainable and need to be supplemented by planting the species both in government forests (as enrichment planting and plantation) and on farms. The price of Prunus africana's bark is, however, low to entice the farmers in its cultivation. One buyer was reported buying the bark from the farmers at Ksh. 300 (US\$ 3.75) per one-ton pickup. There is therefore need to develop the bark's market. The sale of Prunus africana seedlings and/ or seeds can also be a profitable venture for small-scale farmers. In Cameroon, a farmer was documented selling the seeds for US\$ 8 per kilogram [23].

\section{Land size and cultivation level of Prunus africana on farms}

Majorities of the farmers in the study areas are small-scale holders with less than four hectares of land (Table 7). The case is more pronounced in Kakamega where about $89 \%$ of the sampled farmers had two or less hectares of land. The average farm sizes in Kakamega county is 1.5 acres for small scale holders [24]. Cultivation of Prunus africana was higher in the smaller farms $(\leq 2.0 \mathrm{ha}$ ) than in the large farms (negative correlation of $\mathrm{r}=-0.33$ for Kobujoi and $\mathrm{r}=-0.81$ for Kakamega area).

Table 7. Relationship between land size and level of Prunus africana cultivation in Kobujoi and Kakamega

\begin{tabular}{ccccc}
\hline & $\begin{array}{c}\text { Proportion (\%) of interviewed farmers with a } \\
\text { given land size cultivating P. africana } \text { at: }\end{array}$ & Proportion (\%) of P. africana trees on farms at: \\
Farm size (ha) & $\begin{array}{c}\text { Kobujoi } \\
(\mathrm{n}=36)\end{array}$ & $\begin{array}{c}\text { Kakamega } \\
(\mathrm{n}=36)\end{array}$ & $\begin{array}{c}\text { Kobujoi } \\
(\mathrm{n}=111)\end{array}$ & $\begin{array}{c}\text { Kakamega } \\
(\mathrm{n}=77)\end{array}$ \\
\hline$\leq 2.0$ & 42 & 89 & 18 & 92 \\
$2.1-4.0$ & 41 & 6 & 68 & 3 \\
$4.1-6.0$ & 3 & 3 & 1 & 4 \\
$>6.0$ & 14 & 3 & 14 & 1 \\
\hline
\end{tabular}

According to ANOVA, the different farm sizes had significantly different $(\mathrm{P}<0.05)$ number of $P$. africana trees in both Kobujoi and Kakamega (Table 8$)$. Farmers having middle size farms $(2.1-4.0$ ha.) had significantly higher $(\mathrm{P}<0.05)$ number of $P$. africana trees in Kobujoi than the small land size farmers $(\leq 2.0$ ha. $)$ and the big land size (more than $4.0 \mathrm{ha}$ ) farms. At Kakamega, it was those farmers with small farms (2 hectares or less) who had significantly higher $(\mathrm{P}<0.05)$ number of $P$. africana on their farms than the farmers with bigger farms (over 2 hectares pieces of land).

Table 8. The density and mean number of $P$. africana trees in relation to farm sizes at Kakamega and Kobujoi

\begin{tabular}{|c|c|c|c|c|}
\hline \multirow[b]{2}{*}{ Farm size (ha) } & \multicolumn{2}{|c|}{ Density (trees ha ${ }^{-1}$ ) of P. africana trees } & \multicolumn{2}{|c|}{ Mean number of $\mathrm{P}$. africana trees } \\
\hline & Kobujoi & Kakamega & Kobujoi & Kakamega \\
\hline$\leq 2.0$ & 1.2 & 2.2 & $0.60_{\mathrm{a}}$ & $1.94_{a}$ \\
\hline $2.1-4.0$ & 1.5 & 0.3 & $2.11_{\mathrm{b}}$ & $0.06_{b}$ \\
\hline $4.1-6.0$ & 0.2 & 0.5 & $0.03_{\mathrm{a}}$ & $0.08_{b}$ \\
\hline$>6.0$ & 0.3 & 0.1 & $0.42_{\mathrm{a}}$ & $0.03_{\mathrm{b}}$ \\
\hline
\end{tabular}

Note: Means with similar letters indicate that there was no significant difference $(P>0.05$, DMRT)

The higher trees density in Kakamega could have been due to the fact that it had more peasant farmers (with $\leq$ $2.0 \mathrm{ha})$ than Kobujoi. Such farmers have a tradition of practicing agroforestry than large-scale farmers. Their small land divisions have many boundaries, which were cited in the study, as the most preferred niches for tree planting. The findings are in agreement with [25], who concluded that agroforestry is less popular on the larger and commercially viable farms than on smaller holdings of similar land type, and plantation establishment is often supported by off-farm income, so that farm fragmentation may actually lead to increased tree planting.

\subsection{Constraints faced by farmers in domesticating Prunus africana}

Despite the enormous agronomic potential of agroforestry species and methodologies, adoption in sub-saharan Africa remains low [26]. In both Kakamega and Kobujoi, several constraints inhibiting the cultivation of Prunus 
africana were reported (Table 9).

Table 9. Constraints faced by farmers in domesticating Prunus africana in Kobujoi $(\mathrm{n}=36)$ and Kakamega $(\mathrm{n}=36)$

\begin{tabular}{|c|c|c|}
\hline \multirow{2}{*}{ Constraint } & \multicolumn{2}{|c|}{$\%$ of farmers citing a particular constraint at: } \\
\hline & Kobujoi & Kakamega \\
\hline Competition with crops & 53 & 22 \\
\hline Lack of seedlings & 39 & 36 \\
\hline Destruction by livestock & 17 & 17 \\
\hline Pests and diseases & 14 & 0 \\
\hline Destruction by children & 14 & 0 \\
\hline Small land size & 14 & 22 \\
\hline Slow growth of the species & 14 & 14 \\
\hline Drought & 11 & 14 \\
\hline No interest/ reason & 11 & 3 \\
\hline The farmer had just settled & 8 & 3 \\
\hline Land tenure & 6 & 0 \\
\hline Lack of knowledge of its importance & 6 & 0 \\
\hline Customs and beliefs & 3 & 39 \\
\hline Difficulties in identifying planting site & 3 & 0 \\
\hline Already have enough trees in the farm & 3 & 0 \\
\hline Expensive nursery practices & 0 & 3 \\
\hline Lack of time & 0 & 3 \\
\hline
\end{tabular}

In Kobujoi, the species competition with the agricultural crops was cited as the main constraint. Elsewhere, in Cameroon there appeared to be little if any competition between $P$. africana trees and crops (beans, coffee, and potatoes) while on other farms considerable competition with crops, notably maize, growing near the tree was noted [27]. Competition for light, water, nutrients and space between the agricultural crops and Prunus africana trees can be minimized to tolerable levels. Regular pruning, pollarding and/or lopping of the trees will ensure that their crowns are reduced thereby reducing their shading on the under-growing crops. Wide spacing of trees could be maintained if they are to be scattered on the farms and along boundary lines. Thinning may also be done if the tree density is already high.

In Kakamega, certain customs and beliefs associated with the species discouraged the farmers from cultivating it (Table 9). According to the respondents, the tree was not supposed to be planted but rather should grow on its own. If planted, it was a bad omen and associated with death of members of the concerned family. For the same reason, it was also not allowed to grow near a homestead. [28] also noted that in Kakamega, it is believed that if a woman plants trees, her husband will die, or that she will be barren, which is in agreement with what [29] also found. Since traditionally child bearing is an important requirement of stability in marriage, no woman would dare plant trees for fear of becoming barren. Older women who already have the number of children they want, can, however, plant trees and often do so. Similarly, the life of a widow is difficult and no woman would plant trees if doing so is seen as a threat to her husband's life. In the same community, Croton macrostachyus is a common tree species and highly valued for its ability to provide fire especially during the mourning period. Taboos and beliefs related to trees - both positive and negative, have been cited as factors to be considered in tree cultivation by [30]. The communities should therefore be encouraged to practice positive tree-cultivating related taboos/beliefs and more research to verify the facts regarding the negative ones need to be done.

Many farmers in the study areas cited lack of seedlings as a major constraint in cultivating Prunus africana. 
The species has seed storage problems thereby making them difficult to propagate [31]. This hinders the international exchange of seeds and the nursery production of seedlings, as well as farmers' plans to plant the species. This can be solved by sowing fresh seeds which germinate readily [32] or use of wildings. Expensive nursery practices reported in Kakamega was also reported in Oku area, Cameroon in terms of scarce and high costs of polythene tubes, much labour especially for watering and theft of seedlings [8].

Farmers termed drought as another major constraint to tree planting. The actual constraint could, however, have been the competition for labour between planting of agricultural crops and trees. Since the two activities are supposed to be carried at the same time, agricultural crops are given priority and trees are planted when the rainfall has reduced. Lack of enough land, farm layout and land tenure are other major obstacles to growing Prunus africana among the peasant farmers, since the species occur in high potential areas where land is usually scarce. Elsewhere in eastern Zambia, researchers characterize adoption of agroforestry technologies as a function of socio-economic factors such as wealth, gender, labor availability or farm size [33], [34]. Insecurity of tenure or unclear rights to land, are strong disincentives to all forms of long-term investment, including tree growing [35]. Since men are regarded as the owners of the land the family occupies [35], women rarely have power to long term investment such as tree planting. In such cases, it is not only unattractive to invest in tree planting if you are not sure of getting the benefits of the investment, but it may also be unacceptable to plant trees on land which has not legally been confirmed as belonging to the user [35].

Grazing animals do interfere with on-farm Prunus africana trees through browsing (as the species is palatable) and trampling on seedlings and saplings, a problem also reported by farmers in Cameroon [36]. Other problems reported in Cameroon include stem borer, especially in lower altitudes, aphids on seedlings in nurseries, theft of bark and seedlings. This can be minimized by fencing around nurseries and young tree seedlings or encouraging farmers to plant trees in woodlots that are protected from livestock. Incidences of domesticated trees and/ or shrubs death being caused by human/ animal damages and low seed quality were also reported by [9].

Most farmers in Kobujoi and Kakamega lack knowledge of the existence of $P$. africana's bark trade. Where trade exist, the price of the bark is very low, ranging from 0.6-0.7 US\$ and 2.0 US\$ per $\mathrm{kg}$ in Cameroon and Kenya, respectively [20]. This is quite low to motivate the farmers and other bark harvesters. A farmer in Kobujoi said that the only buyer of Prunus africana bark was buying the bark at a throw-away price of Ksh. 300 per one-ton pick-up (Pers. com). Elsewhere in Mau, farmers were clearing their forest, cutting down Prunus africana for quick cash from its charcoal and pave way for agricultural practices (tea plantations) [37]. When compared with Acacia mearnsii commercially cultivated for tanning, the price of Prunus africana's bark is a thousand times more costly than that one of Acacia mearnsii [13]. So, if the marketing can be organised the species can be of great value to farmers.

Prunus africana farming may also pose another problem. The tree takes long to mature and start having some tangible benefits. Farmers in both Kakamega and Kobujoi cited the slow growth of the species as one of the major constraints discouraging its domestication. According to [38], Prunus africana takes 12-15 years before the bark contains the active ingredients that treat BPH. The species has, however, been described as a fairly fast growing indigenous tree, comparable with Acacia mearnsii, a fast growing species commercially grown for tannin production [39]. An alternative to waiting for over 12 years before harvesting the bark would be for farmers to cultivate only young Prunus africana trees (2-3 years old) for the extract processing. This would give farmers a shorter rotation crop to cultivate, but feasibility depends on the level of active ingredient in the young trees, which discredit this possibility [38].

\section{Conclusions and Recommendations}

Since Prunus africana is threatened with extinction, the use of indigenous forests as sources of the species products need to be supplemented by planting the species both in government forests (as enrichment planting and plantation) and on farms. Generally, farmers adjacent to both Kakamega and Kobujoi forests have a wide range of tree species in their farms, with the preferred trees providing fuelwood, timber, poles, medicine, shade and fruits. Prunus africana provide most of these products, hence a priority species for domestication in the two areas. There is the need for ethnobotanical surveys to document more detailed information about Prunus africana throughout its ecological range. This is important in order to store the quickly disappearing indigenous knowledge on its uses and discover other hidden crucial information of $P$. africana that affect its domestication process. Its use in 
treating BPH and subsequent value of its bark is not widely known to the communities. This calls for community enlightment on this valuable information as it could entice more farmers to conserve the species. This should also go hand in hand with development of the bark trade.

The various constraints associated with on-farm conservation of Prunus africana need to be addressed. Due to its seed recalcitrant nature, the use of wildings for propagation should be encouraged together with capacity building on nursery establishment and management. The communities should be encouraged to continue naturing the trees in their preferred planting sites (farm boundaries, watersheds) and trees scattered on farms need to be well spaced and pruned regularly to minimize their competition with growing crops. In Kakamega, the community should be educated to dissociate the species with bad omen. Despite small land sizes being mentioned as one of the constraints facing the domestication of $P$. africana, it is clear from the study that farmers with small land sizes had more $P$. africana trees than the ones with big farms.

\section{Acknowledgement}

The authors are greatly indebted to the ICRAF's ANAFE Fellowship which funded the research while Kenya Forestry Research Institute (KEFRI) funded its publication. The following people helped in field data collection: Mr \& Mrs G. Muchai, B. Bitok, D. Shikuku, E. Buleti and D. Buleti. The following people assisted in data analysis, proof reading the document and literature search: J. Kinyanjui, J. Maua, J. Hitimana, H. Mutuma, T. Tandese, J. Were (late), M. Munjuga, S. Carsan, J. Muriuki, S. Muasya and R. Ruigu.

\section{References}

[1] Albrecht, J. (1993). The seed handbook of Kenya. GTZ Forestry Seed Centre, Nairobi, Kenya.

[2] Orwa C, Mutua, A., Kindt R., Jamnadass R, Anthony, S. (2009). Agroforestree Database:a tree reference and selection guide version 4.0 (http://www.worldagroforestry.org/sites/treedbs/treedatabases.asp).

[3] Maundu, P. and Tengnäs T. (eds) (2005). Useful Trees and Shrubs for Kenya. Technical Handbook No. 35. Nairobi, Kenya: World Agroforestry Centre-Eastern and Central Africa Regional Programme (ICRAF-ECA), 484p.

[4] FAO. (1996). Appendix 6. Forest genetics resources priorities in Africa. Report of the eighth session of the FAO panel of experts on forest gene resources, held in Rome, 28-30 June 1993, pp. 24-25. FAO, Rome.

[5] Cunningham, M., Cunningham, A.B., and Schippmann, U. (1997). Trade in Prunus africana and the implementation of CITES. German Federal Agency for Nature Conservation, Bonn. p.52.

[6] Leakey, R. and Simons, T. (1997). Domestication — many things to many people. In Agroforestry Today 9 (2):5.

[7] Madofe, S., Andrew D., Mombo F. (2006). Developing a strategy for sustainable income generation from a valuable medicinal plant, Prunus africana in Kilimanjaro region. Final report, Research and Poverty Alleviation (REPOA) project. Morogoro: Sokoine University of Agriculture.

[8] Franzel, S., Ayuk, E., Cunningham, A.B., Asanga, C., Duguma, B. (2010). Bark for sale: The adoption potential of Prunus africana as an agroforestry tree for small-scale farmers in Cameroon. In: Cunningham, A. B. et al. Bark: use, management and commerce in Africa, Winter 2010, vol. 17, Advances in Economic Botany.

[9] Maina, P. and Mandila, M. (2019). Domestication and Survival of Selected Medicinal Trees and Shrubs in Chapereria Division West Pokot County Kenya. Asian Journal of Advanced Research and Reports, 3(2), 1-17. https://doi.org/10.9734/ajarr/2019/v3i230082.

[10] Rotich, J., Sirmah, P., Mengich, E., Okelo, P. (2017). Agroforestry trees in Kapsaret, Kenya: Socio-economic perspectives influencing availability, preference and utilization. International Journal of Agroforestry and Silviculture ISSN 2375-1096 Vol. 5 (5), pp. 315-325, May, 2017.

[11] Bryce, J.M. (1967). The commercial timbers of Tanzania. Utilization section, Tanzania Forest Division, Moshi. p.139.

[12] Hankins, M. (1989). Renewable energy in Kenya. Motif Creative Arts Ltd, Nairobi, Kenya. p.118.

[13] Cunningham, A.B. (1995). An economic evaluation of Prunus africana cultivation for medicinal bark: A case study from Cameroon. Unpublished report. WWF/UNESCO/Kew People and Plants Initiative, Godalming.

[14] Suda, C. (1992). Literature review on the use of indigenous forest in Kenya. Nairobi: KIFCON

[15] Kokwaro, J.O. (1976). Medicinal plants of east Africa. East African Literature Bureau, Nairobi. p. 384.

[16] Njoroge, G.N, Kaibui, I.M, Njenga, P.K, Odhiambo, P.O. (2010). Utilisation of priority traditional medicinal plants and local people's knowledge on their conservation status in arid lands of Kenya (Mwingi District). Journal of Ethnobiology and 
Ethnomedicine. 2010; 6(1):22-28.

[17] Otieno. E.N., Analo C. (2012). Local indigenous knowledge about medicinal plants in and around Kakamega forest in western Kenya. F1000 Research. 2012;1(40). DOI: 10.12688/f1000research.1-40.

[18] Kipkore, W, Wanjohi, B, Rono, H, Kigen, G. (2014). A study of the medicinal plants used by the marakwet community in Kenya. Journal of Ethnobiology and Ethnomedicine. 2014; 10(24). DOI: 10.1186/1746-4269-10-24.

[19] Jeanrenaud, S. (1991). The conservation-development interface: A study of forest use, agricultural practices and perceptions of the rain-forest, Elinde forest, South west Cameroon. Report to UK Overseas Development Administration, London.

[20] Cunningham, A.B. and Mbenkum F.T. (1993). Review of sustainability of harvesting Prunus africana bark in Cameroon: A medicinal plant in international trade. People and Plants Working Paper, 2: 1-28. UNESCO, Paris.

[21] Nsom, C.L., Dick, J., (1992). An Ethnobotanical Tree Survey of the Kom Area. Unpublished Report Prepared for the Ijim Mountain Forest Project.

[22] Letouzey, R. (1978). Flore du Cameroun : 20. Rosacées Musée d'histoire naturelle, Paris.

[23] Dawson, I.K. and Fondoun J.M. (1996). Prunus africana collection report. ICRAF, Nairobi, Kenya.

[24] County government of Kakamega, (2015). Average farm sizes. https://kakamega.go.ke/economy.

[25] Harrison, S. \& Herbohn, J. (2005). Small-scale Forestry 4: 471. https://doi.org/10.1007/s11842-005-0029-2.

[26] Kiptot, E., P. Hebinck, S. Franzel, and P. Richards (2007). Adopters, testers or pseudo-adopters: Dynamics of the use of improved tree fallows by farmers in western Kenya. Agricultural Systems 94 (2): 509-519.

[27] Stewart, K. M. (2003). The African cherry ( Prunus africana): Can lessons be learned from an over-exploited medicinal tree? Journal of Ethnopharmacology 89 (2003) 3-13.

[28] Chavangi, N.A., (1989). "Socio-economic issues in agroforestry." Paper presented at Agroforestry Seminar, Thuci iver Lodge, November 1989. Nairobi: Ministry of Agriculture, $9 \mathrm{pp}$.

[29] Ipara H.I. (1992). Socio-economic factors affecting the participation of women in agroforestry activities in Sabatia division in Vihiga, Kakamega District, Kenya. M.Phil. thesis, Moi University Kenya.

[30] Foley, G. and Geoffrey, B. (1984). Farm and Community Forestry. Earthscan Energy Information Programme. Technical report No. 3. IIED, London.

[31] Sunderland, T. and Nkefor, J. (1997). Conservation through cultivation a case study: The propagation of Pygeum - Prunus africana. Tropical Agricultural Association Newsletter, December: 5-13.

[32] Geldenhuys, C.J. (1981). Prunus africana in the Bloukrans River Gorge, Southern Cape. South African Forestry Journal, 118:61-66.

[33] Franzel, S., D. Phiri, and F.R. Kwesiga. (2002). Assessing the adoption potential of improved tree fallows in Eastern Zambia. Trees on the farm: Assessing the adoption potential of agroforestry practices in Africa, ed. Franzel, S. and S.J. Scherr. Wallingford, UK: CAB International.

[34] Ajayi, O. C., Akinnifesi, F. K., Gudeta, S., and Chakeredza, S. (2007). Adoption of renewable soil fertility replenishment technologies in southern African region: lessons learnt and the way forward', Natural Resource Forum 31, 306-317.

[35] Tengnäs, B. (1994). Agroforestry extension manual for Kenya. ICRAF, Nairobi, Kenya. pp. 177.

[36] Hall, J., E. O’Brien, and F. Sinclair (2000). Prunus africana: A monograph, in Publication No 18. School of Agricultural and Forest Sciences, University of Wales Bangor: Bangor. p. 104.

[37] Ndam, N. and Ewusi B. (1999). An assessment of Prunus africana situation in Cameroon, Kenya and Madagascar. Unpublished report.

[38] Lodoen, D. (2000). Back from the brink. Ecoforum, Short Rains: The East African Environment and Development Magazine, 24 (4): 40-41.

[39] Cunningham, A.B., Ayuk, E., Franzel, S., Duguma, B. and Asanga, C. (1998). An economic evaluation of medicinal tree cultivation: Prunus africana in Cameroon. People and Plants Working Paper 6, UNESCO, Paris. 